\title{
FRACTIONS OF INORGANIC PHOSPHORUS IN FINNISH MINERAL SOILS
}

\author{
ARmi KaIla \\ University of Helsinki, Department of Agricultural Chemistry
}

Received November 15, 1963

Since CHANG and JACKson in 1957 introduced their procedure for the fractionation of soil phosphorus, this method has been employed in numerous works in various parts of the world (e.g. 2, 4, 5, 6, 8, 9, 10, 11, 13, 15, 16, 17, 18, 20, 21). In spite of the criticism to which the method has been subjected $(1,7,13,18$, etc.), it has aided in clarifying the difficult problem of the estimation of soil phosphorus bound by different components. Particularly important is the possibility to determine separately the aluminium bound phosphorus and the iron bound phosphorus, even though this differentiation may not be quite exact.

In a previous paper (15) the writer published results on the fractions of inorganic phosphorus in various layers of some mineral soils in Finland. In the present work, a larger material is analyzed, and an attempt is made to find some of the factors on which the distribution of the soil inorganic phosphorus into variously bound fractions may depend.

\section{Material and methods}

The material of the present work consists of 363 samples of mineral soils collected from various parts of the country. There are 213 samples from the plough layer of cultivated soils, 25 samples from the surface layer of virgin soils, mostly forest soils, and 125 samples from the deeper layers of virgin and cultivated soils from the depths between $20 \mathrm{~cm}$ and $70 \mathrm{~cm}$.

According to the results of the mechanical analysis, the soils were grouped into the following textural classes accepted in Finland: 
Content of fractions

Ø $<0.002 \mathrm{~mm} \quad 0.002-0.02 \mathrm{~mm} \quad 0.02-0.2 \mathrm{~mm}$

$\begin{array}{lccc}\text { Fine sand } & <30 \% & <50 \% & >50 \% \\ \text { Loam } & <30 \% & 20-50 \% & 20-50 \% \\ \text { Silt } & <30 \% & >50 \% & <50 \% \\ \text { Clay loam } & 30-60 \% & 20-50 \% & 20-50 \% \\ \text { Sandy clay } & 30-60 \% & <20 \% & 20-70 \% \\ \text { Silty clay } & 30-60 \% & 20-70 \% & <20 \% \\ \text { Heavy clay } & >60 \% & <40 \% & <40 \%\end{array}$

The $\mathrm{pH}$ of the soil was measured in $1: 2.5$ suspension in $0.02 \mathrm{~N} \mathrm{CaCl}_{2}$ by the glass electrode. Aluminium and iron were extracted by Tamm's acid ammonium oxalate solution. Aluminium was determined by the Aluminon method and iron by the sulfosalicylic acid procedure, after the destruction of the organic matter by ignition.

Table 1. Soil samples

\begin{tabular}{|c|c|c|c|c|c|}
\hline & \multirow{2}{*}{$\begin{array}{l}\text { Number } \\
\text { of } \\
\text { samples }\end{array}$} & \multirow[b]{2}{*}{$\mathrm{pH}^{*}$} & \multirow{2}{*}{$\begin{array}{l}\text { Inorg. P } \\
\mathrm{mg} / \mathrm{kg}^{*}\end{array}$} & \multicolumn{2}{|c|}{ Ammonium oxalate soluble } \\
\hline & & & & $\begin{array}{c}\mathrm{Al} \\
\mathrm{mmol} / \mathrm{kg}^{*}\end{array}$ & $\begin{array}{c}\mathrm{Fe} \\
\mathrm{mmol} / \mathrm{kg}^{*}\end{array}$ \\
\hline \multicolumn{6}{|l|}{ Cultivated soils } \\
\hline \multicolumn{6}{|l|}{ Surface soils } \\
\hline Sand & 19 & $5.4 \pm 0.3$ & $540 \pm 140$ & $91 \pm 17$ & $58 \pm 19$ \\
\hline Fine sand & 38 & $5.4 \pm 0.1$ & $600 \pm 80$ & $110 \pm 22$ & $63 \pm 7$ \\
\hline Loam & 47 & $5.2 \pm 0.1$ & $570 \pm 65$ & $95 \pm 8$ & $75 \pm 6$ \\
\hline Silt & 22 & $5.2 \pm 0.2$ & $690 \pm 55$ & $101 \pm 27$ & $80 \pm 4$ \\
\hline Clay loam & 29 & $5.3 \pm 0.2$ & $760 \pm 90$ & $141 \pm 30$ & $124 \pm 28$ \\
\hline Sandy clay & 8 & $5.7 \pm 0.6$ & $790 \pm 145$ & $121 \pm 39$ & $98 \pm 19$ \\
\hline Silty clay & 42 & $5.2 \pm 0.1$ & $680 \pm 40$ & $125 \pm 20$ & $106 \pm 11$ \\
\hline Heavy clay & 8 & $5.3 \pm 0.4$ & $810 \pm 165$ & $136 \pm 49$ & $130 \pm 59$ \\
\hline \multicolumn{6}{|l|}{ Deeper layers } \\
\hline Sand and fine sand & 25 & $5.2 \pm 0.1$ & $340 \pm 45$ & $153 \pm 32$ & $67 \pm 15$ \\
\hline Loam and silt & 23 & $5.4 \pm 0.3$ & $590 \pm 75$ & $62 \pm 14$ & $66 \pm 16$ \\
\hline Clay & 46 & $5.5 \pm 0.3$ & $640 \pm 55$ & $94 \pm 13$ & $89 \pm 19$ \\
\hline \multicolumn{6}{|l|}{ Virgin soils } \\
\hline \multicolumn{6}{|l|}{ Surface soils } \\
\hline Sand and fine sand & 16 & $4.6 \pm 0.4$ & $300 \pm 80$ & $105 \pm 11$ & $72 \pm 11$ \\
\hline Loam and silt & 5 & $4.5 \pm 0.3$ & $540 \pm 240$ & $126 \pm 57$ & $107 \pm 63$ \\
\hline Clay & 4 & $6.1 \pm 2.2$ & $510 \pm 85$ & $86 \pm 33$ & $89 \pm 49$ \\
\hline \multicolumn{6}{|l|}{ Deeper layers } \\
\hline Sand and fine sand & 11 & $5.2 \pm 0.5$ & $410 \pm 150$ & $185 \pm 102$ & $72 \pm 27$ \\
\hline Loam and silt & 6 & $5.8 \pm 0.9$ & $550 \pm 140$ & $80 \neq 87$ & $64 \pm 51$ \\
\hline Clay & 14 & $6.3 \pm 0.8$ & $700 \pm 100$ & $98 \pm 24$ & $116 \pm 41$ \\
\hline
\end{tabular}

* Mean values with the confidence limits at 95 per cent level. 
The total content of inorganic phosphorus represents the difference between the total content of phosphorus determined by the fusion method (19) and the content of organic phosphorus estimated as the average of the results obtained by the writer's modification of the acid-alkali extraction and by a simple ignition method (14).

The fractionating of inorganic phosphorus was performed by the procedure of CHANG and JACKSON (3). Because of the very low amount of phosphorus extracted by $\mathrm{N} \mathrm{NH} \mathrm{Nl}_{4} \mathrm{Cl}$, this fraction was in most cases not determined Instead of neutral $\mathrm{NH}_{4} \mathrm{~F}$, the slightly alkaline extractant ( $\mathrm{pH} 8.5$ ) recommended by FIFE (7) was used. When the reductant soluble phosphorus was determined, a mixture of $\mathrm{HClO}_{4}$ and $\mathrm{H}_{2} \mathrm{SO}_{4}$ was used for the destruction of the organic matter, and the disturbing effect of iron on the colour intensity was avoided by dilution. The occluded phosphorus was extracted by $0.1 \mathrm{~N} \mathrm{NaOH}$. All the phosphorus determinations were performed by the writer's modification of the molybdenum blue method (12).

The soil samples are listed in Table 1. There are 109 samples of sand and fine sand soils, 103 samples of loam and silt soils, and 151 samples of clay soils. On the average, most of the soil groups are acid, even if allowance is made to the fact that the $\mathrm{pH}$-values were measured in $0.02 \mathrm{~N} \mathrm{CaCl}_{2}$, and these results may be about $0.3-0.8 \mathrm{pH}$-degree lower than those determined in the water suspension. The virgin surface soils of a coarser texture seem to be more acid than the other groups.

The mean values for the content of inorganic phosphorus tend to increase from sand to clay samples. The cultivated surface soils appear to be richer in inorganic phosphorus than the corresponding groups of virgin surface soils, probably because of the application of phosphate fertilizers, and the fact that soils of a higher fertility are likely to be reclaimed. Owing to the large variation in the content of inorganic phosphorus in each soil group, statistically significant differences between the group means exist in a few cases only.

The acid ammonium oxalate solution seems to extract more aluminium than iron from the soils of a coarser texture, while this tendency is less marked in the soils of the finer texture, as far as it may be found at all. The cultivated surface samples of the clay soils tend to be, on the average, significantly richer in iron than those of the sand and fine sand soils, and a similar tendency may be found also in regard to the content of aluminium. In the deeper layers, however, the sand and fine sand soils appear to contain more aluminium than do the corresponding samples of clay soils.

\section{Fractions of inorganic phosphorus in various kind of soils}

The results of the fractionation of inorganic phosphorus in the samples are recorded in Table 2 as mean values for the various groups of soils. "Al-P» stands for the fraction soluble in alkaline $\mathrm{NH}_{4} \mathrm{~F}$, $" \mathrm{Fe}$ - $\mathrm{P} n$ stands for the alkali-soluble fraction, and ${ } \mathrm{Ca}-\mathrm{P}$, for the acid-soluble part of inorganic phosphorus.

The highest average content of ${ }^{\prime A l}-\mathrm{P}_{\|}$is found in the surface samples of the sand soils, the fine sand soils of the corresponding layer coming second with a 
Table 2. Fractions of inorganic phosphorus, $\mathrm{P} \mathrm{mg} / \mathrm{kg}$

(Mean values with the confidence limits at 95 per cent level.)

\begin{tabular}{|c|c|c|c|c|c|}
\hline & $\mathrm{Al}-\mathrm{P}$ & Fe-P & Ca-P & $\begin{array}{l}\text { Reductant } \\
\text { soluble P }\end{array}$ & $\begin{array}{c}\text { Occluded } \\
\text { P }\end{array}$ \\
\hline \multicolumn{6}{|l|}{ Cultivated soil } \\
\hline \multicolumn{6}{|l|}{ Surface soils } \\
\hline Sand & $135 \pm 55$ & $130 \pm 50$ & $125 \pm 35$ & $60 \pm 10$ & $5 \pm 1$ \\
\hline Fine sand & $120 \pm 35$ & $160 \pm 35$ & $155 \pm 30$ & $60 \pm 10$ & $5 \pm 1$ \\
\hline Loam & $65 \pm 20$ & $140 \pm 25$ & $195 \pm 35$ & $80 \pm 10$ & $10 \pm 1$ \\
\hline Silt & $80 \pm 25$ & $160 \pm 20$ & $290 \pm 40$ & $70 \pm 10$ & $10 \pm 1$ \\
\hline Clay loam & $85 \pm 20$ & $235 \pm 50$ & $190 \pm 30$ & $85 \pm 20$ & $20 \pm 5$ \\
\hline Sandy clay & $95 \pm 55$ & $210 \pm 65$ & $235 \pm 100$ & $120 \pm 95$ & $20 \pm 15$ \\
\hline Silty clay & $70 \pm 20$ & $170 \pm 25$ & $230 \pm 30$ & $65 \pm 10$ & $15 \pm 5$ \\
\hline Heavy clay & $60 \pm 30$ & $240 \pm 90$ & $185 \pm 90$ & $135 \pm 90$ & $40 \pm 20$ \\
\hline \multicolumn{6}{|l|}{ Deeper layers } \\
\hline Sand and fine sand & $40 \pm 10$ & $65 \pm 15$ & $120 \pm 25$ & $40 \pm 10$ & $5 \pm 5$ \\
\hline Loam and silt & $15 \pm 5$ & $100 \pm 45$ & $315 \pm 85$ & $60 \pm 15$ & $10 \pm 2$ \\
\hline Clay & $15 \pm 5$ & $120 \pm 35$ & $245 \pm 40$ & $90 \pm 15$ & $35 \pm 1$ \\
\hline \multicolumn{6}{|l|}{ Virgin soils } \\
\hline \multicolumn{6}{|l|}{ Surface soils } \\
\hline Sand and fine sand & $15 \pm 5$ & $50 \pm 15$ & $85 \pm 55$ & $50 \pm 20$ & $5 \pm 1$ \\
\hline Loam and silt & $25 \pm 30$ & $145 \pm 170$ & $190 \pm 135$ & $50 \pm 45$ & $5 \pm 3$ \\
\hline Clay & $20 \pm 20$ & $80 \pm 40$ & $235 \pm 245$ & $75 \pm 40$ & $15 \pm 10$ \\
\hline \multicolumn{6}{|l|}{ Deeper layers } \\
\hline Sand and fine sand & $50 \pm 30$ & $80 \pm 35$ & $155 \pm 105$ & $50 \pm 20$ & $5 \pm 2$ \\
\hline Loam and silt & $10 \pm 25$ & $45 \pm 50$ & $380 \pm 195$ & $45 \pm 35$ & $5 \pm 3$ \\
\hline Clay & $15 \pm 5$ & $125 \pm 90$ & $340 \pm 95$ & $65 \pm 20$ & $20 \pm 5$ \\
\hline \multicolumn{6}{|l|}{ All samples } \\
\hline Sand and fine sand & $85 \pm 15$ & $110 \pm 15$ & $135 \pm 20$ & $50 \pm 5$ & $5 \pm 1$ \\
\hline Loam and silt & $55 \pm 10$ & $130 \pm 15$ & $250 \pm 30$ & $70 \pm 5$ & $10 \pm 1$ \\
\hline Clay & $50 \pm 10$ & $165 \pm 20$ & $235 \pm 20$ & $85 \pm 5$ & $25 \pm 5$ \\
\hline
\end{tabular}

statistically equal mean value. In general, the content of the phosphorus supposed to be bound by aluminium is distinctly higher in the plough layer than in the deeper layers or in the virgin soils. This, obviously, is due to the accumulation of a large part of the fertilizer phosphorus into this fraction (13). Even in the deeper layers, the samples of sand and fine sand soils tend to contain more "Al-P» than the other soils.

In the groups of the cultivated soils, the content of alkali-soluble phosphorus is, on the average, distinctly higher than that of the fluoride-soluble phosphorus except in the samples of sand and fine sand soils in which these fractions seem to be almost equal. The clay soils tend to contain more $" \mathrm{Fe}-\mathrm{P} n$ than the sand and fine sand soils, but, owing to the large variation, the differences between the mean values are only in a few cases statistically significant. Apparently, a part of the fertilizer phosphorus has accumulated also in this fraction, since the samples of the 
deeper layers and those of the virgin soils seem to contain less iron bound phosphorus than do the plough layers of the corresponding soil groups.

The fraction of the acid-soluble phosphorus which is supposed to be bound by calcium has the lowest mean values in the sand and fine sand soils. The silt and the silty clay samples of the cultivated surface soils seem to have a fairly high average content of ${ } \mathrm{Ca}-\mathrm{P}$. . It is noteworthy that the plough layer is not richer in the acid-soluble phosphorus than the deeper layers. This is in accordance with the observations that, in our soils, the soluble fertilizer phosphorus will seldom accumulate into this fraction (13). It has been found that often in our soils, the calcium bound phosphorus fraction will increase with the depth at the expence of the aluminium and iron bound fractions (15). According to the present average values, the fraction of the "Ca-P» appears to be of the same order, at least, as that of the $" \mathrm{Fe}-\mathrm{P} \|$, and thus higher than the ${ }^{\mathrm{A}} \mathrm{Al}-\mathrm{P} \|$ fraction, except in the plough layer of the sand and fine sand soils where all these three fractions are, on the average, equal.

The reductant soluble phosphorus, or phosphorus dissolved by the dithionitecitrate reduction chelation procedure is supposed to represent iron phosphate the solution of which during the alkali-treatment is prevented by an iron oxide coating. The mean content of this kind of phosphorus tends to be in the plough layer of the sand and fine sand soils lower than the Al-bound fraction, but in all the other groups it is at least of the same order, or even higher than this first fraction. In the samples of the cultivated surface soils, the reductant soluble phosphorus seems, on the average, to be lower than the alkali-soluble fraction; in the deeper layers and in the virgin soils differences between these two fractions are not significant.

According to ChANG and JAckson (3), the last fraction determined, or the occluded phosphorus, is likely to be mainly aluminium phosphate and some barrandite-like aluminium-iron phosphate. This fraction is very low in all the samples of sand, fine sand, loam and silt, but in the samples of the clay soils somewhat higher values were obtained. Since the applied phosphate fertilizers are not supposed to be accumulated in the fractions of the reductant soluble or occluded phosphorus, there are no reasons to expect significant differences in these fractions between the cultivated surface soils and the corresponding kind of soil of the deeper layers or of the virgin soils.

In Table 2 are also recorded the mean values for all the 109 samples of sand and fine sand soils, the 103 samples of loam and silt soils, and the 151 samples of clay soils. The differences in the mean values of these groups may not, however, be attributed to the textural differences only, since the relative numbers of the samples of the cultivated surface soils and those of the deeper layers and of virgin soils are not equal in them. Yet, in spite of the somewhat lower relative number of the cultivated surface samples in the sand and fine sand soil group, this has a higher mean content of the $" \mathrm{Al}-\mathrm{P}$ " and a lower content of "Ca-P» than the samples of the finer texture.

This tendency to the occurence of larger amounts of fluoride-soluble phosphorus in the sand and fine sand soils than in the other kind of soils is even more distinctly revealed by the relative contents of the inorganic phosphorus fractions reported in Table 3 . The part of inorganic phosphorus extracted by alkali appears 
Table 3. Percentage of phosphorus fractions of the total amount of inorganic phosphorus extracted (Mean values with the confidence limits at 95 per cent level)

\begin{tabular}{|c|c|c|c|c|c|}
\hline & 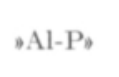 & ${ }_{n} \mathrm{Fe}-\mathrm{P}$ & ${ }^{\mathrm{Ca}} \mathrm{P} P$ & $\begin{array}{l}\text { Reductant } \\
\text { soluble P }\end{array}$ & $\begin{array}{c}\text { Occluded } \\
\text { P }\end{array}$ \\
\hline \multicolumn{6}{|l|}{ Cultivated surface soils } \\
\hline Sand and fine sand & $26 \pm 3$ & $31 \pm 2$ & $30 \pm 3$ & $12 \pm 2$ & $1 \pm 0.3$ \\
\hline Loam and silt & $13 \pm 2$ & $28 \pm 2$ & $43 \pm 4$ & $14 \pm 2$ & $2 \pm 0.4$ \\
\hline Clay & $13 \pm 2$ & $34 \pm 2$ & $36 \pm 3$ & $14 \pm 1$ & $3 \pm 0.5$ \\
\hline \multicolumn{6}{|l|}{ Virgin surface soils } \\
\hline Sand and fine sand & $8 \pm 4$ & $24 \pm 8$ & $42 \pm 12$ & $23 \pm 8$ & $2 \pm 1$ \\
\hline Loam and silt & $6 \pm 7$ & $35 \pm 19$ & $46 \pm 38$ & $12 \pm 22$ & $1 \pm 2$ \\
\hline Clay & $5 \pm 7$ & $18 \pm 14$ & $55 \pm 40$ & $18 \pm 28$ & $4 \pm 4$ \\
\hline \multicolumn{6}{|l|}{ Deeper layers } \\
\hline Sand and fine sand & $16 \pm 4$ & $24 \pm 3$ & $42 \pm 7$ & $15 \pm 4$ & $1 \pm 0.4$ \\
\hline Loam and silt & $3 \pm 2$ & $20 \pm 6$ & $60 \pm 10$ & $12 \pm 3$ & $2 \pm 0.6$ \\
\hline Clay & $3 \pm 1$ & $25 \pm 5$ & $49 \pm 5$ & $17 \pm 3$ & $7 \pm 1$ \\
\hline \multicolumn{6}{|l|}{ All samples } \\
\hline Sand and fine sand & $22 \pm 2$ & $29 \pm 2$ & $35 \pm 3$ & $13 \pm 2$ & $1 \pm 0.3$ \\
\hline Loam and silt & $11 \pm 1$ & $25 \pm 2$ & $49 \pm 4$ & $13 \pm 2$ & $2 \pm 0.3$ \\
\hline Clay & $9 \pm 1$ & $30 \pm 2$ & $42 \pm 3$ & $15 \pm 1$ & $4 \pm 0.7$ \\
\hline
\end{tabular}

to be almost independent on the soil texture, but the percentage of the acid-soluble phosphorus tends to be highest in the loam and silt soils. In the few surface samples of the virgin sand and fine sand soils, poor in total inorganic phosphorus, the reductant soluble fraction appears to be fairly high; in all the other groups the relative content of this fraction is almost of the same rather low order. The occluded phosphorus shows some tendency to higher proportions in the clay soils.

In all the soil groups, except in the cultivated surface samples of sand and fine sand and clay soils, the average proportion of the acid soluble fraction is significantly higher than those of the other fractions. This calcium bound phosphorus is the dominating form of the inorganic phosphorus extracted in almost 60 per cent of all the samples. Table 4 shows in more detail the distribution of the samples in the various groups according to their dominant form of inorganic phosphorus extracted. Only in the surface layer of sand and fine sand soils the $" \mathrm{Fe}-\mathrm{P} n$ is dominating in a higher number of samples than is the case with the "Ca-P». It is of interest to notice that there are samples in which the aluminium bound fraction is the largest one, and that this is not only the case with one fifth of the surface samples of sand and fine sand soils, but in one tenth of the samples of the deeper layers of these soils, and even in the surface samples of some clay soils. These latter soils have a particularly high content of oxalate-soluble Al. The number of the samples of the virgin surface soils in which the reductant soluble phosphorus represents the largest fraction is remarkable. 
Table 4. The dominating form of inorganic phosphorus in the soil samples (Expressed as the percentage of the number of the samples)

$\mathrm{Ca}-\mathrm{Pe}, \mathrm{P}, \quad$ Al-P, $\quad \begin{gathered}\text { Reductant } \\ \text { soluble } \mathrm{P}\end{gathered}$

Cultivated surface soils

Sand and fine sand soils

Loam and silt

Clay

Virgin surface soils

Sand and fine sand

Loam and silt

Clay

Deeper layers

Sand and fine sand

Loam and silt

Clay

All samples

Sand and fine sand

Loam

Clay

$\begin{array}{ll}33 & 44 \\ 61 & 35 \\ 55 & 37\end{array}$

\section{1}

60

75

64

79

73

43

66

63
44
35
37

\section{4}

20

$-$

\section{0}

17

22

36

29

30
21

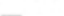

$\begin{array}{ll}6 & 2\end{array}$

Attention must be paid to the fact that the sum of the amounts of phosphorus in the five fractions determined is lower than the corresponding total amount of inorganic phosphorus calculated as the difference of the contents of total phosphorus and organic phosphorus. In the various groups this average deficit varies from 65 to $150 \mathrm{ppm}$ or from 12 to 32 per cent of the content of total inorganic phosphorus. This residual phosphorus is of the same order as found by MADL (18). He supposes that this phosphorus belongs to apatite occurring inside of silicate and quartz crystals. In the present material it represents amounts which are of the same order as alkali-soluble phosphorus in the unfertilized soils. Thus the proportion of inorganic phosphorus bound by calcium would be markedly higher than the figures for the acid-soluble fraction indicate. An examination of the individual cases show that only in very few samples, mostly Litorina soils, this total calcium bound phosphorus would be lower than the sum of the alkali-soluble and reductant soluble fractions.

Factors connected with the distribution of inorganic phosphorus into various fractions

The occurence of phosphorus bound by sesquioxides or calcium is supposed to depend on the soil reaction, the former being dominant in the acid soils and the latter in soils with a higher $\mathrm{pH}$. In the present material the distribution of the 
Table 5. Correlation coefficients between $\mathrm{pH}$ and phosphorus fractions

\begin{tabular}{|c|c|c|c|c|c|}
\hline & $\mathrm{Al}-\mathrm{Pl}$ & $\mathrm{Fe}-\mathrm{P}$ & Ca-P & $\mathrm{Al}-\mathrm{P} / \bullet \mathrm{Fe}-\mathrm{P}$ & ${ }_{*} \mathrm{Ca}-\mathrm{P} / / * \mathrm{Fe}-\mathrm{P}$ \\
\hline \multicolumn{6}{|l|}{ Cultivated surface soils } \\
\hline Sand and fine sand & $0.49^{* * *}$ & $0.53^{* * *}$ & $0.49^{* * *}$ & 0.11 & -0.31 \\
\hline Loam and silt & $0.28^{*}$ & 0.12 & 0.13 & 0.23 & -0.02 \\
\hline Clay & -0.12 & -0.14 & 0.03 & 0.01 & $0.25^{*}$ \\
\hline Virgin surface soils & 0.17 & -0.12 & $0.68^{* * *}$ & $0.51^{* *}$ & $0.56^{* *}$ \\
\hline \multicolumn{6}{|l|}{ Deeper layers } \\
\hline Sand and fine sand & 0.23 & 0.27 & $0.35^{*}$ & -0.15 & 0.14 \\
\hline Loam and silt & $-0.59^{* * *}$ & $-0.61^{* * *}$ & $0.77^{* * *}$ & $-0.40^{*}$ & $0.79 * * *$ \\
\hline Clay & -0.10 & $-0.53^{* * *}$ & $0.70^{* * *}$ & $0.56^{* * *}$ & $0.51 * * *$ \\
\hline \multicolumn{6}{|l|}{ All samples } \\
\hline Sand and fine sand & $0.48 * * *$ & $0.49 * * *$ & $0.54 * * *$ & $0.27 * *$ & $0.32 * * *$ \\
\hline Loam and silt & 0.04 & $-0.25^{* *}$ & $0.47 * * *$ & -0.07 & $0.54 * * *$ \\
\hline Clay & -0.14 & $-0.41 * * *$ & $0.60^{* * *}$ & -0.05 & $0.50^{* * *}$ \\
\hline All & 0.11 & -0.11 & $0.55^{* * *}$ & 0.07 & $0.36^{* * *}$ \\
\hline
\end{tabular}

inorganic phosphorus into the various fractions appears to be rather poorly correlated with the soil $\mathrm{pH}$ (Table 5). According to the total linear correlation coefficients between $\mathrm{pH}$ and $n \mathrm{Al}-\mathrm{P}_{n},{ }_{\mathrm{Fe}}-\mathrm{P}_{n}$ or $\mathrm{Ca}-\mathrm{P}_{n}$, respectively, only in the virgin surface soils, and in the samples of loam and silt soils and clay soils from the deeper layers a somewhat closer positive correlation may be found between $\mathrm{pH}$ and "Ca- $\mathrm{P}$. The negative correlation found between $\mathrm{pH}$ and the ${ }^{\mathrm{F}} \mathrm{Fe}-\mathrm{P} \|$ in the deeper layers of the soils of the finer texture is rather low, and in the sand and fine sand soils even a low positive correlation appears to exist between these variables. Also the connection between the $\mathrm{Al}-\mathrm{P} "$ and $\mathrm{pH}$ is mostly negligible with the exception of a low negative correlation in the deeper layers of the loam and silt soils.

The total linear correlation coefficients were calculated also for the relation between $\mathrm{pH}$ and the three forms of phosphorus expressed as a percentage of the total amount of inorganic phosphorus extracted by the procedure. These results are of the same order as the former ones, only the low positive correlation between $\mathrm{pH}$ and the various fractions in the sand and fine sand soils disappears, and the relation between $\mathrm{pH}$ and ${ } \mathrm{Fe}-\mathrm{P} n$ in some of the groups seems to be more in accordance with the theories (cf. Table 7 , the column ${ }^{\prime \prime 1}{ }_{13}$ ).

The dependence on the $\mathrm{pH}$ of the relation of the $" \mathrm{Fe}-\mathrm{P}$ " with the two other forms was studied by calculating the correlation coefficients also reported in Table 5 . It could be supposed that the higher the $\mathrm{pH}$ is the higher would also be both the ratios $" \mathrm{Al}-\mathrm{P} n / n \mathrm{Fe}-\mathrm{P}_{n}$ and of ${ }_{n} \mathrm{Ca}-\mathrm{P} n / n \mathrm{Fe}-\mathrm{P}_{n}$. This, however, does not appear to be the case except for the latter ratio, in the samples of loam and silt soils from the deeper layers.

Thus, it seems that in the present material the soil $\mathrm{pH}$ is not playing any important role among the factors on which the distribution of the inorganic phos- 
Table 6. Correlation between fluoride- and alkali-soluble phosphorus and aluminium and iron extracted by acid ammonium oxalate.

\section{Correlation coefficients between \\ , $\mathrm{Al}-\mathrm{P}$, and $\mathrm{Al}, \mathrm{Fe}-\mathrm{P}$, and $\mathrm{Fe}, \mathrm{Al}-\mathrm{P}, / \mathrm{Fe}-\mathrm{P}$, and $\mathrm{Al} / \mathrm{Fe}$}

Cultivated surface soils
Sand and fine sand
Loam and silt
Clay
Virgin surface soils
Deeper layers
Sand and fine sand
Loam and silt
Clay
All samples
Sand and fine sand
Loam and silt
Clay
All

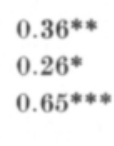

0.26

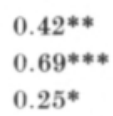

0.12

$0.35^{* * *}$

$0.63^{* * *}$

$0.33^{* * *}$

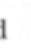
( 
Table 7. Correlation between ${ }^{\mathrm{Fe}} \mathrm{P}-\mathrm{P}$ expressed as a percentage of the inorganic $\mathrm{P}$ extracted (1) and ammonium oxalate soluble Fe (2) and soil $\mathrm{pH}$ (3)

\begin{tabular}{lllll}
\hline & $\mathrm{r}_{12}$ & $\mathrm{r}_{13}$ & $\mathrm{r}_{12,3}$ & $\mathrm{R}_{1(23)}^{2}$ \\
\hline Cultivated surface soils & & & & \\
Sand and fine sand & $0.52^{* * *}$ & 0.27 & $0.49^{* * *}$ & 0.30 \\
Loam and silt & $0.48^{* * *}$ & -0.09 & $0.49^{* * *}$ & 0.24 \\
Clay & $0.86^{* * *}$ & $-0.33^{*}$ & $0.84^{* * *}$ & 0.74 \\
& & & & \\
Virgin surface soils & $0.34^{*}$ & $-0.62^{* * *}$ & 0.34 & 0.48 \\
& & & & \\
Deeper layers & & & & \\
Sand and fine sand & 0.30 & 0.06 & 0.29 & 0.09 \\
Loam and silt & $0.68^{* * *}$ & $-0.82^{* * *}$ & 0.33 & 0.71 \\
Clay & $0.84^{* * *}$ & $-0.81^{* * *}$ & $0.78^{* * *}$ & 0.86 \\
All samples & & & & \\
Sand and fine sand & $0.32^{* * *}$ & -0.03 & $0.32^{* * *}$ & 0.10 \\
Loam and silt & $0.66^{* * *}$ & $-0.51^{* * *}$ & $0.57^{* * *}$ & 0.50 \\
Clay & $0.82^{* * *}$ & $-0.70^{* * *}$ & $0.77^{* * *}$ & 0.79 \\
All & $0.69^{* * *}$ & $-0.46^{* * *}$ & $0.69^{* * *}$ & 0.60 \\
& & & & \\
\hline
\end{tabular}

Also in the loam and silt samples from the deeper layers more than 70 per cent of this variation may be connected with the content of iron and with $\mathrm{pH}$.

\section{Discussion}

According to CHANG and JACKson (4) soil factors such as $\mathrm{pH}$, degree of chemical weathering, activities of various cations, and fertilizer practice play their role in the formation of various discrete chemical forms of phosphate. In addition to these, several other factors may exert their effect, e.g. the parent material, soil organic matter, the redox-potential, the activity of soil micro-organisms and plant roots etc. Therefore, the results of a fractionating of soil phosphorus may often seem to be contradictory to the prevailing suppositions.

In the present study, the dominance of calcium bound phosphorus even in acid soils, and the very low correlation between the soil $\mathrm{pH}$ and the different phosphorus fractions, in general, are results which may seem to be surprising. Also the relatively high content of aluminium bound phosphorus in sand and fine sand soils is not in accordance with the reports that this kind of phosphorus is likely to be connected to the finer fractions while calcium bound phosphorus is typical to the sand fraction $(20,22)$.

The writer finds no reasons to suppose that the high amounts of acid-soluble phosphorus obtained would to any marked degree contain reductant soluble phosphorus. In all the cases studied a second extraction with acid dissolved very little 
phosphorus (cf. 1). It is therefore likely that the acid soluble fraction represented calcium bound forms the occurence of which may be taken to indicate a fairly low degree of weathering in these soils (4). The increase in this fraction with depth, found in a previous study (15), and also pointed out by the present data, corroborates this assumption. Provided the residual inorganic phosphorus not determined in the present work really is apatite inside the mineral crystals, our soils would contain a large proportion of unweathered mineral phosphate.

The fairly high content of fluoride-soluble phosphorus in the sand and fine sand soils may be connected with the relatively high ratio of aluminium to iron in these soils. In the sand and fine sand soils the average ratio of ammonium oxalate soluble aluminium to iron is 2.0 while it in the soils of the finer texture is about 1.2. The corresponding ratios of ${ } \mathrm{Al}-\mathrm{P} \|$ to $n \mathrm{Fe}-\mathrm{P}_{\|}$are 0.8 and 0.3 , respectively. Thus in the sand and fine sand soils of the present material, the phosphate dissolved from apatite, or mineralized from organic compounds, or applied as fertilizers, may to a larger extent become bound by the aluminium complex than is the case in the other soil groups. An other problem is why these sand and fine sand soils do contain relatively more oxalate soluble aluminium as compared with the iron content than do the other soils.

It seems that the ratio of the aluminium and iron contents is more important than their absolute amounts in determining the distribution of phosphorus between the aluminium and the iron bound fractions. Also it seems, that variation in the contents of iron and aluminium will to a somewhat higher degree than the soil reaction explain the variation in the $" \mathrm{Fe}-\mathrm{P} \|$ and $" \mathrm{Al}-\mathrm{P}$.

In the present paper only linear correlation coefficients between $\mathrm{pH}$ and the phosphorus fractions were computed. There appeared, however, to be no reasons to suppose that a curvilinear relationship would have better explained the relation between these variables. It is true that Hsu and JAcKson (11) have found curvilinear relation of $\mathrm{pH}$ to percentage of $" \mathrm{Ca}-\mathrm{P} n$ of the total active inorganic phosphorus, but this was the case only within each individual profile.

Relatively little attention has been paid in the present paper to the reductant soluble and occluded phosphorus. The main reason for this is that the writer considers the determination of the former fraction to be liable to marked errors. The results are reported only to give some idea of the order of magnitude of this kind of phos-

phorus. In no case does it represent in our soils such dominant part of soil phosphorus as is the case in the old soils $(1,4)$.

\section{$S u m m$ ary}

Inorganic phosphorus in 363 samples of Finnish mineral soils was fractionated by the procedure of CHANG and JAckson.

The average content of total inorganic phosphorus determined as the difference of the total phosphorus and organic phosphorus tended to increase from sand to clay soils. The sand and fine sand soils appeared to be richer in fluoride-soluble 
phosphorus but poorer in acid-soluble phosphorus than the other groups of soils. The part of phosphorus extracted by alkali seemed to be almost independent on the soil texture.

In about 60 per cent of the samples the acid-soluble phosphorus was the dominant inorganic phosphorus fraction, in spite of the often high acidity of the soil. This, in connection with the rather low content of reductant soluble phosphorus, was taken to indicate the relatively low degree of weathering in these soils.

The higher contents of fluoride-soluble and alkali-soluble phosphorus in the surface samples of the cultivated soils as compared with the corresponding kind of virgin soils or soils from the deeper layers may be mainly attributed to the application of phosphorus fertilizers and to a somewhat higher degree of weathering.

The soil $\mathrm{pH}$ did not seem to play any important role among the factors related to the distribution of inorganic phosphorus into various fractions in the present material. This was particularly true in the cultivated surface soils. It is likely, that in our soils the variation in the contents of active iron and aluminium will to a higher degree than $\mathrm{pH}$ explain the variation in the fractions of alkali-soluble and fuoride-soluble phosphorus. The relatively high content of the latter fraction in the sand and fine sand soils as compared with the soils of the finer texture could be related to the higher ratio of ammonium oxalate soluble aluminium to iron in the former soils.

\section{R E F E R E N C ES}

(1) Aung Khin \& Leeper, G. W. 1960. Modifications in Chang and Jackson's procedure for fractionating soil phosphorus. Agrochimica IV: 246-254.

(2) Сhai, M. C. \& Caldwell, A. C. 1959. Forms of phosphorus and fixation in soils, Soil Sci. Soc. Amer. Proc. 23: 458-460.

(3) Chang, S. C. \& Jackson, M. L. 1957. Fractionation of soil phosphorus. Soil Sci. 84: 133-144.

(4) Chang, S. C. \& Jackson, M. L. 1958. Soil phosphorus fractions in some representative soils. J. Soil Sci. 9: 109-119.

(5) Chu, W. K. \& Chang, S. C. 1960. Forms of phosphorus in the soils of Taiwan. J. agric. Ass. China 30: 1-12. (Ref. Soils \& Fert. XXIV: 555.)

(6) Daiber, K. 1960. Verlagerung von Bodenbestandteilen unter einem Gebirgshochmoor. Z. Pflanzenern. Düng. Bodenk. 89: 55-61.

(7) FIFE, C. V. 1959. An evaluation of ammonium fluoride as a selective extractant for aluminiumbound soil phosphate: II. Soil Sci. 87: 83-88.

(8) Hamilton, H. A. \& Lessard, J. R. 1960. Phosphorus fractions in a soil sampled at different depths and the effect of lime and fertilizer on oats and clover in a greenhouse test. Canad. J. Soil. Sci. 40: $71-79$.

(9) Hanley, K. 1962. Soil phosphorus forms and their availability to plants. Irish J. Agr. Res. 1: $192-193$.

(10) Heinemann, C. G. 1962. Der Einfluss von Düngung, pH-Wert und Wasserhaushalt auf die PVerteilung in Böden. Dissert. Techn. Hochschule Hannover, 90 p.

(11) Hsu, P. H. \& JAcKson, M. L. 1960. Inorganic phosphate transformations by chemical weathering in soils as influenced by $\mathrm{pH}$. Soil Sci. $90: 16-24$.

(12) KAILA, A. 1955. Studies on the colorimetric determination of phosphorus in soil extracts. Acta Agr. Fenn. 83: 25-47. 
(13) Kaita, A. 1961. Fertilizer phosphorus in some Finnish soils. J. Sci. Agric. Soc. Finland 33: 131-139.

(14) - 1962. Determination of total organic phosphorus in samples of mineral soils. Ibid. 34: $187-196$.

(15) $\quad-1$ 1963. Phosphorus conditions at various depths in some mineral soils. Ibid. 35: 69-79.

(16) Laverty, J. C. \& McLean, E. O. 1961. Factors affecting yields and uptake of phosphorus by different crops: 3. Soil Sci. 91: 166-171.

(17) MacKenzie, A. F. 1962. Inorganic soil phosphorus fractions of some Ontario soils as studied using isotopic exchange and solubility criteria. Canad. J. Soil. Sci 42: 150-156.

(18) MadL, W. 1961. Bindung und Verteilung des Phosphors in Böden der Bayerischen Horänenlandschaft. Veröff. Inst. Bodenk. u. Standortslehre d. Forstl. Forsch. Anst. München, $175 \mathrm{p}$.

(19) Muir, J. W. 1952. The determination of total phosphorus in soil. Analyst 77: $313-317$.

(20) Scheffer, F. \& Kloke, A. \& Hempler, K. 1960. Die Phosphatformen in Boden und ihre Verteilung auf die Korngrössenfraktionen. Z. Pflanzenern. Düng. Bodenk. 91: 240-252.

(21) WEIR, C. C. \& SoPER, R. J. 1962. Adsorption and exchange studies of phosphorus in some Manitoba soils. Canad. J. Soil Sci. 42: $31-42$.

(22) Williams, E. G. \& Saunders, W. M. H. 1956. Distribution of phosphorus in profiles and particle size fractions of some Scottisch soils. J. Soil Sci. 7: $90-108$.

S E L OS T U S :

KIVENNÅISMAITTEMME EPÅORGAANISEN FOSFORIN FRAKTIOISTA

ARMI KaILA

Yliopiston maanviljelyskemian laitos, Helsinki

СнANGin ja JACKsonin menetelmää käyttäen fraktioitiin 363 kivennäismaanäytteen epäorgaaninen fosfori.

Viljelysmaiden muokkauskerroksen verraten runsaat fluoridiin ja emäkseen uuttuvat fosforin määrät ovat todennäkőisesti lannoitefosforista peräisin joskin rapautumisella voi olla oma osuutensa siinä, ettă nämä fraktiot ovat keskimäärin suuremmat kuin vastaavissa maalajeissa luonnontilaisilla mailla tai syvemmissä kerroksissa. Hiekka- ja hietamaat näyttivät sisältävän runsaammin fluoridiin uuttuvaa fosforia kuin hienojakoisemmat maalajit. Tämä voitiin kytkeä hiekka- ja hietamaiden raudan pitoisuuteen verrattuna suureen aluminiumin määrään.

Useissa maissa happoon liukeneva fosfori oli vallitsevana fraktiona huolimatta siitä, että monet näistä maista olivat melko happamia. Tämän, samoin kuin okludoituneen fosforin niukkuuden katsottiin olevan osoituksena maitten verraten heikosta rapautumisasteesta.

Epäorgaanisen fosforin jakaantuminen eri fraktioihin ei näyttänyt sanottavasti riippuvan maan happamuudesta. Todennäköisesti maan raudan ja aluminiumin pitoisuus selittää suuremman osan raudan ja aluminiumin sitoman fosforin määrissä havaittavista vaihteluista. 